\title{
DAYA TANGGAP KUALITAS PELAYANAN PERAWAT PASIEN RAWAT INAP BEDAH DI RSUD LABUANG BAJI
}

\author{
Irma Muslimin, Nurhayati \\ Jurusan Keperawatan Poltekkes Kemenkes Mamuju
}

\begin{abstract}
Development of health as one of the national development efforts for the achievement of awareness, willingness and ability to live a healthy life for every resident in order to realize optimal health status. This study aims to determine responsiveness to service quality inpatient surgical nurse at the Hospital Labuang Makassar Baji. The study population was the whole patient/client while undergoing inpatient surgery in hospitals Labuang Baji. with the number of 211 patients. Sampling patients were calculated using a minimum sample size with number of 86 patients. The results showed that the quality of nursing service inpatient surgery is reviewed capability of quickly handling patient complaints values obtained Beta 0.414 (positive) aspects of fast action when a patient requires values obtained Beta 0.310 (positive) and the aspect of providing information that is clear and easily understandable obtained Beta value of 0,303 (positive). Hospital Labuang Baji should hold regular training to nurses in order to improve the ability of nurses to handle patient complaints quickly.
\end{abstract}

\section{Keyword: responsiveness, quality of service.}

\section{PENDAHULUAN}

Pembangunan kesehatan sebagai salah satu upaya pembangunan nasional untuk tercapainya kesadaran, kemauan dan kemampuan hidup sehat bagi setiap penduduk agar dapat mewujudkan derajat kesehatan yang optimal. Selaras dengan tujuan pembangunan kesehatan adalah terdapatnya kemampuan untuk hidup sehat bagi setiap penduduk, agar dapat mewujudkan derajat kesehatan masyarakat yang optimal, sebagai salah satu unsur kesejahteraan umum dari tujuan nasional, untuk itu perlu ditingkatkan upaya guna memperluas dan meningkatkan pelayanan kesehatan kepada masyarakat dan perlu adanya penyesuaian ketersediaan fasilitas kesehatan yang sesuai dengan standar pelayanan, sehingga diperoleh suatu pelayanan kesehatan dengan mutu yang baik dan biaya yang terjangkau. Kualitas Pelayanan adalah Penampilan yang pantas dan sesuai (sesuai dengan standar) dari suatu intervensi yang diketahui aman, yang dapat memberikan hasil kepada masyarakat yang bersangkutan dan yang telah mempunyai kemampuan untuk menghasilkan dampak pada kematian, kesakitan, ketidakmampuan dan kekurangan gizi (Roemer dan Aguilar, 1988, dalam Kotler, 2003:127).

Tujuan pelayanan kesehatan adalah tercapainya derajat kesehatan masyarakat yang memuaskan harapan dan kebutuhan masyarakat melalui pelayanan yang efektif oleh pemberi pelayanan dan kebutuhan pemberi pelayanan, pada institusi pelayanan yang diselenggarakan secara efisien. Interaksi ketiga pilar utama pelayanan kesehatan yang serasi, selaras dan seimbang, merupakan panduan dari kepuasan tiga pihak, dan ini merupakan pelayanan kesehatan yang memuaskan (satisfactory healty care) (Muhaimin, 2005: 58).

Mutu pelayanan yang diberikan tidak akan pernah sempurna, karena setiap pasien adalah pribadi yang unik, sehingga pelayanan tidak selalu dapat memuaskan, karena mutu pelayanan terhadap kepuasan pasien sangat ditentukan oleh pelaksanaan pelayanan SK Menteri Kesehatan RI No/44 tentang Rumah Sakit tahun 2009 menyebutkan bahwa "Rumah Sakit umum adalah Rumah Sakit sebagai salah satu fasiltas pelayanan kesehatan yang sangat diperlukan dalam mendukung penyelenggaraan upaya kesehatan". Oleh karena itu, pelayanan yang maksimal adalah pelayanan yang sesuai dengan standar yang menjadi dasar penentuan kepuasaan maksimal pasien.

Penyelenggaraan pelayanan di rumah sakit mempunyai karakteristik dan organisasi yang sangat kompleks. Pengukuran terhadap produk jasa yang sifatnya intangible. Menurut para peneliti, didapati bahwasanya para konsumen memiliki beberapa kriteria yang digunakan sebagai tolok ukurnya pengevaluasian dan pengukuran produk jasa tersebut, yaitu: Bukti Langsung (tangibles) yang meliputi fasilitas fisik sarana prasarana, perlengkapan utama dan pendukung, pegawai 
internal (kantor) dan eksternal (dilapangan) serta sarana komunikasi. Kehandalan (reliability) yang memberikan jasa pelayanan serta informasi seakurat dan sesegera mungkin dengan tingkat hasil memuaskan, Daya Tanggap/Daya Serap (responsiveness) yang secara tanggap dan cepat memberikan pelayanan kepada pelanggannya serta dengan tingkat serap yang baik atas informasi yang diberikan, Jaminan (assurance) yang mencakup lingkup dasar pengetahuan, kemampuan, kesopanan serta sifat pegawai/staf yang dapat dipercaya, bebas dari bahaya, resiko atau keragu-raguan dalam melaksanakan tugas serta tanggungjawab tanpa dengan adanya pengawasan yang sangat ketat, tetapi berdasarkan sadar disiplin, Empati (emphaty) yang meliputi karakter personal yang dapat memudahkan melakukan hubungan atau komunikasi yang baik, perhatian pribadi dan memahami kebutuhan para pelanggan.

Kepuasan pelanggan adalah suatu keadaan dimana keinginan, harapan, dan keperluan pelanggan dipenuhi, suatu pelayanan dinilai memuaskan bila ia dapat memenuhi kebut uhan dan harapan pelangganya. Ada beberapa faktor yang dapat dipertimbangkan dalam menilai suatu pelayanan, yaitu: ketepatan waktu, dapat dipercaya, kemampuan teknis, diharapkan berkualitas dan harga yang sepadan.

Hasil penelitian sebelumnya sebagaimana dilaporkan oleh Hendrajana (2005) tentang pengaruh kualitas pelayanan medis, paramedis, dan penunjang medis terhadapkepuasan pelanggan rawat inap di RSUD Dr. Moewardi Surakarta menunjukkan bahwaterdapat pengaruh signifikan antara berbagai variabel kualitas pelayanan terhadap kepuasan pelanggan rawat jalan di RSUD Dr. Moewardi Surakarta.

\section{BAHAN DAN METODE Jenis Penelitian}

Penelitian ini menggunakan pendekatan cross sectional yaitu suatu penelitian untuk mempelajari dinamika korelasi antara variabel bebas dan terikat dengan cara pendekatan, observasi atau pengumpulan data sekaligus pada suatu saat.

\section{Waktu dan Lokasi Pelaksanaan}

Penelitian ini dilaksanakan pada tahun 2012 di Rumah Sakit Umum Daerah Labuang Baji

\section{Populasi dan Sampel}

Populasi penelitian adalah seluruh pasien/klien yang sementara menjalani rawat inap bedah di RSUD Labuang Baji dengan jumlah 211 pasien. Sampel dalam penelitian ini adalah sebagian dari populasi penelitian. Pengambilan sampel pasien dihitung dengan menggunakan Minimal size dengan jumlah sampel 86 pasien.

\section{Teknik Pengumpulan Data}

Data yang diambil dari penelitian ini adalah data primer dan data sekunder. Data primer diambil dari kuesioner langsung pasien rawat inap bedah yang memenuhi kriteria inklusi.

Data sekunder diambil dari rekam medik rumah sakit, meliputi jumlah kunjungan pasien rawat inap bedah, laporan tahunan RSUD Labuang Baji Makassar, data identitas pasien yang diperoleh dari kartu status pasien rawat inap bedah dan catatan lain yang terdapat di rumah sakit.

\section{Teknik Analisa Data}

Analisis dilakukan dalam bentuk analisis kuantitatif yang penyajiannya dalam angka-angka yang dapat diukur dan dihitung. Tingkat ukuran yang dipakai dalam pengukuran variabel adalah dengan skala Likert, dimana seorang responden dihadapkan pada beberapa pertanyaan kemudian diminta memberikan jawabannya.

Hasil perhitungan dari skor atau nilai kemudian digunakan dalam analisis statistik. Dilakukan dengan bantuan komputer, menggunakan program Excel dan SPSS untuk membuktikan hubungan dan pengaruh antar variabel-variabel penelitian dengan menggunakan uji data dengan analisis regresi linear berganda.

\section{HASIL PENELITIAN}

Dalam penelitian ini daya tanggap kualitas pelayanan perawat pasien rawat inap Bedah di RSUD Labuang Baji dilihat dari kemampuan yang cepat dalam menangani keluhan pasien, tindakan cepat saat pasien membutuhkan dan bagaimana perawat memberikan Informasi yang jelas dan mudah dimengerti. Rata-rata skor jawaban kategori kemampuan yang cepat dalam menangani keluhan pasien adalah 10,93 dan standar deviasi 2,325 sehingga standar deviasi lebih kecil dari nilai rata-rata. Rata-rata skor jawaban kategori kemampuan yang cepat dalam menangani keluhan pasien adalah 18,43 dan standar deviasi 
1,7323 sehingga standar deviasi lebih kecil dari nilai rata-rata. Rata-rata skor jawaban kategori kemampuan yang cepat dalam menangani keluhan pasien adalah 5,76 dan standar deviasi 1,701 sehingga standar deviasi lebih kecil dari nilai rata-rata. Rata-rata skor jawaban kategori kemampuan yang cepat dalam menangani keluhan pasien adalah 35,12 dan standar deviasi 5,612 sehingga standar deviasi lebih kecil dari nilai rata-rata.

Hasil analisis regresi linier berganda menunjukkan bahwa nilai 0,414 pada kategori kemampuan yang cepat dalam menangani keluhan pasien, nilai 0,310 pada kategori tindakan cepat saat pasien membutuhkan, nilai 0,303 pada kategori memberikan informasi yang jelas dan mudah dimengerti masingmasing bernilai positif yang berarti semakin tinggi kemampuan yang cepat dalam menangani keluhan pasien, tindakan cepat saat pasien membutuhkan dan memberikan informasi yang jelas dan mudah dimengerti maka akan semakin tinggi pula kualitas pelayanan (Tabel 1).

Tabel 1. Hasil Analisis Regresi Linier Berganda Kualitas Pelayanan Perawat Pasien Rawat Inap Bedah di RSUD Labuang Baji Makassar tahun 2012

\begin{tabular}{|c|c|c|c|c|c|}
\hline \multirow[t]{2}{*}{ Variabel Daya Tanggap } & \multicolumn{2}{|c|}{$\begin{array}{l}\text { Unstandardized } \\
\text { Coefficient }\end{array}$} & \multirow{2}{*}{$\begin{array}{c}\text { Standardized } \\
\text { Coefficient } \\
\text { Beta }\end{array}$} & \multirow[t]{2}{*}{$\mathbf{t}$} & \multirow[t]{2}{*}{ Sig. } \\
\hline & B & Std. Error & & & \\
\hline Constant &,- 010 &, 005 & & $-1,954$ &, 054 \\
\hline $\begin{array}{l}\text { Kemampuan yang cepat dalam } \\
\text { menangani keluhan pasien }\end{array}$ &, 333 & ,000 & ,414 & 712,026 & 000 \\
\hline $\begin{array}{l}\text { Tindakan cepat saat pasien } \\
\text { membutuhkan }\end{array}$ &, 334 & ,000 & ,310 & 800,916 & ,000 \\
\hline $\begin{array}{l}\text { Memberikan informasi yang } \\
\text { jelas dan mudah dimengerti }\end{array}$ & ,333 & ,001 & ,303 & 550,632 &, 000 \\
\hline
\end{tabular}

\section{PEMBAHASAN}

Kemampuan pengambilan keputusan yang tepat dan akurat sangat diperlukan bagi tenaga paramedis untuk dapat menyelamatkan pasien yang dihadapi. Pola-pola perilaku pengambilan keputusan yang dilakukan oleh tenaga paramedis ini melibatkan aspek-aspek fisik maupun psikis yang sangat besar, mengandung resiko yang cukup tinggi antara keselamatan dan kematian dari pasien yang sedang dihadapi. Hasil penelitian ini sejalan dengan penelitian yang dilakukan oleh Dwi Retno (2010) yang mengemukakan bahwa daya tanggap berpengaruh positif dan signifikan terhadap kepuasaan konsumen.

Batasan pelayanan kesehatan yang bermutu adalah pelayanan kesehatan yang dapat memuaskan setiap pemakai jasa sesuai dengan tingkat kepuasan rata-rata penduduk, serta penyelenggaraannya sesuai kode etik dan standar yang telah ditetapkan. Kualitas pelayanan kesehatan di rumah sakit merupakan suatu fenomena unik, sebab dimensi dan indikatornya dapat berbeda diantara orangorang yang terlibat dalam pelayanan kesehatan. Untuk mengatasi perbedaan dipakai suatu pedoman yaitu hakikat dasar dari penyelenggaraan pelayanan kesehatan, yaitu memenuhi kebutuhan dan tuntutan para pemakai jasa pelayanan kesehatan. Pasien di rumah sakit akan memberikan apresiasi yang tinggi kepada perawat ketika pada saat mereka membutuhkan perawat dapat melakukan tindakan dengan cepat. Hal ini merupakan salah satu kriteria dalam penilaian pasien terhadap kualitas pelayanan atau sarana kesehatan.

Pelayanan yang diharapkan membuat pasien merasa puas (customer satisfaction) adalah dengan memberikan kepada pelanggan apa yang betul-betul mereka butuhkan dan inginkan, bukan memberikan apa yang kita pikirkan dibutuhkan oleh mereka. Memberikan pelayanan yang berkualitas kepada pelanggan merupakan merupakan hal penting yang mempengaruhi kinerja kompetitif organisasi dan kualitas maupun produktivitas yang tinggi, merupakan hal yang penting. untuk memenuhi harapan pelanggan, rumah sakit dituntut untuk dapat memberikan pelayanan prima ataupun dengan mengembangkan pemanfaatan informasi yang diperoleh dari hasil riset pasar dalam suatu kerangka strategic. 


\section{KESIMPULAN}

1. Kualitas pelayanan perawat pasien rawat inap bedah ditinjau kemampuan yang cepat dalam menangani keluhan pasien 53,99\% pasien merasa tidak puas. Hasil analisis regresi linier berganda diperoleh nilai Beta 0,414 yang bernilai positif sehingga dapat dikatakan bahwa semakin tinggi kemampuan perawat dalam menangani keluhan pasien dengan cepat, maka semakin tinggi penilaian pasien terhadap kualitas pelayanan yang diberikan.

2. Kualitas pelayanan perawat pasien rawat inap bedah ditinjau dari aspek tindakan cepat saat pasien membutuhka, 61,63\% pasien merasa sangat puas. Hasil analisis regresi linier diperoleh nilai Beta 0,310 yang bernilai positif sehingga dapat dikatakan bahwa semakin tinggi tindakan cepat perawat saat pasien membutuhkan, maka semakin tinggi penilaian pasien terhadap kualitas pelayanan yang diberikan. Nilai $p=0,000 \quad(p<0,05)$, hal ini berarti bahwa tindakan cepat perawat saat pasien membutuhkan signifikan terhadap kualitas pelayanan.

3. Kualitas pelayanan perawat pasien rawat inap bedah ditinjau dari aspek memberikan informasi yang jelas dan mudah dimengerti, $58,53 \%$ pasien merasa kurang puas. Hasil analisis regresi linier berganda diperoleh nilai Beta 0,303 yang bernilai positif sehingga dapat dikatakan bahwa semakin baik kemampuan perawat dalam memberikan informasi yang jelas dan mudah dimengerti oleh pasien, maka semakin tinggi penilaian pasien terhadap kualitas pelayanan yang diberikan. Nilai $\mathrm{p}=0,000(\mathrm{p}<0,05)$, hal ini berarti bahwa kemampuan memberikan informasi yang jelas dan mudah dimengerti oleh pasien signifikan terhadap kualitas pelayanan.
DAFTAR PUSTAKA

Azwar A. (1996). Menjaga Mutu Pelayanan Kesehatan, Pustaka Sinar Harapan, Jakarta.

Assauri, Sofjan. (2003). Customer Service yang Baik Landasan Pencapaian Customer Satisfaction dalam Usahawan, No. 01, Tahun XXXII, Januari, hal. 25 - 30 . Jakarta.

Barnes, James G. (2003). Secrets of Customer Relationship Management (Terjemahan Andreas Winardi), Penerbit Andi, Yogjakarta.

Ghozali, Imam. (2001). Aplikasi Analisis Multivariate dengan Program SPSS, Badan Penerbit Universitas Diponegoro, Semarang.

Hasan Iqbal. (2002). Pokok-Pokok Materi Metodologi Penelitian dan Aplikasinya, Jakarta, Ghalia Indonesia.

Henri. (2003). Analisis Pengaruh Kualitas Pelayanan terhadap Kepuasan Pasien Rawat Inap di Rumah Sakit PKU Muhammadiyah Yogyakarta, (Tesis), Program Pascasarjana Universitas Islam Indonesia, Yogjakarta.

Hendrajana. (2005). Pengaruh Kualitas Pelayanan terhadap Kepuasan Pelanggan Rawat Jalan di RSUD Dr. Moewardi Surakarta (Tesis), Program Pascasarjana Universitas Muhammadiyah Surakarta, Surakarta.

Kotler, Philip. (2003). Marketing Management. New Jersey: Prentice Hall.

Muhaemin. (2005). Analisis Faktor-faktor yang Mempengaruhi Kepuasan Nasabah PT. Bank BPD Jateng Cabang Surakarta (Tesis), Universitas Muhammadiyah Surakarta, Surakarta. 